\title{
SOAPSTONE RESEARCH IN MEMORY OF J. D. LOVE, Grand Teton National Park, Wyoming
}

\author{
RICHARD ADAMS + WYOMING STATE ARCHAEOLOGIST \\ UNIVERSITY OF WYOMING $\uparrow$ LARAMIE
}

\begin{abstract}
$\checkmark \quad$ ABSTRACT
Operating under a grant from the University of Wyoming-National Park Service Research Station, personnel from the Office of the Wyoming State Archaeologist and volunteers located and re-recorded two soapstone sources in Grand Teton National Park: 48TE1255 B Slim Lawrence's Asbestos Mine B and 48TE529. Over on the west side of the Tetons, in the Caribou-Targhee National Forest, we located and recorded a historic mine, three new prehistoric sites, and a previously unrecorded soapstone source: 48TE1646 -the Rammel Mountain talc mine. Among the six newly discovered sites is 48TE1647, which contains two broken soapstone bowl preforms and a broken vessel associated with other prehistoric artifacts. This is interpreted to be evidence of prehistoric manufacture of soapstone bowls in Wyoming. More work needs to be done at this site as
\end{abstract} well as other in the Tetons.

\section{$\downarrow$ INTRODUCTION}

Thanks to a grant from the University of Wyoming-National Park Service Research Station, personnel from the Office of the Wyoming State Archaeologist and three volunteers re-recorded two soapstone sources in Grand Teton National Park and located and recorded six new prehistoric sites in the Caribou-Targhee National Forest including an aboriginally utilized soapstone source. This work honors the late geologist John David Love, who mapped the geology of the Tetons and maintained an active interest in the prehistoric inhabitants of Wyoming.

\section{Environment Setting}

The project took place on both sides of the Teton Range (Figure 1). On the east side, we surveyed the Owl and Berry creek drainages in the northern backcountry of Grand Teton National Park. Terrain in this area is steep and rugged (Turner 2000). It is so steep that we had trouble surveying in the vicinity of 48TE529, where the talus moved underfoot with every step.

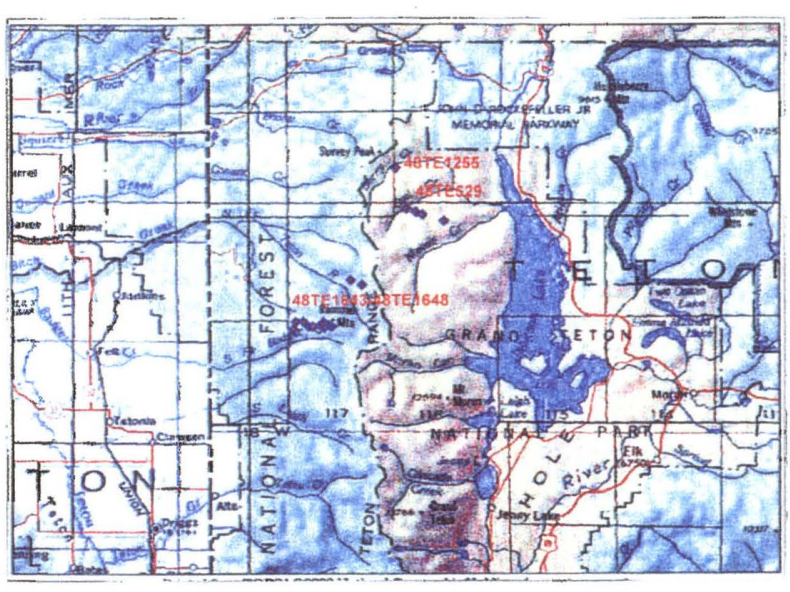

Figure 1. Map of northwestern Wyoming showing general location of project area.

In Grand Teton National Park we started on the western shore of Jackson Lake near the base of Harem Hill and followed the Berry Creek trail to the Upper Berry Creek Patrol Cabin, where we ascended a pass 
west of Forellen Peak and then dropped into the Owl Creek drainage. We followed the Owl Creek trail down to Jackson Lake and then north back to Harem Hill.

Owl and Berry Creek Canyons have relatively flat valley floors, but there is an abrupt transition from the valley floor to steep slopes that continue up to the summits of Forellen and Owl peaks. Soapstone sources occur on the heavily timbered north and northwest-facing slopes of these peaks. Springs and seeps are common in the numerous gullies and avalanche chutes that dissect the north-facing slopes. Vegetation in the valley floors consists of willows along the creek. Sage or mixed conifer-aspen forest grow on the terraces. The north facing slopes are covered with spruce and fir at lower elevations and limber-whitebark pines up to treeline. A band of scree and talus rings the base of nearly vertical rock outcrops that form the peaks at highest elevations.

On the west side of the Tetons, our survey took place in the Jedediah Smith Wilderness in the CaribouTarghee National Forest, in Wyoming. We surveyed a western spur of Rammel Mountain that forms a prominent ridge which can be followed all the way to a pass just south of Rammel Peak. East of the pass there is easy access to Bitch Creek. South of the ridge, and 1300 feet below, is the Badger Creek valley. To the north are the numerous gullies and streams coming off Rammel Mountain. Steep slopes and timber obscure visibility on either side of the ridge line. Dominant species are whitebark pine and Douglas fir.

Commercial logging outside the wilderness boundary has created a mosaic of open ground and mature conifer forests. Both logging and mining preceded creation of the Jedediah Smith Wilderness. An historic mine and a ruined cabin are inside the wilderness area boundary. Also, numerous snowmobile parts were observed inside the wilderness boundary. It is likely that there was vehicular access to 48TE2646- the Rammel Talc Mine before the creation of the Jedediah Smith Wilderness. This is based on the presence of dozer cuts at the mine.

Two of the six sites recorded on the west side of the Tetons were in the lower reaches of a cirque-like area. This bouldery subalpine area is characterized by long-lasting snowpack in the spring that gives way to alpine flowers fringing numerous rocky rivulets running through wet meadows interspersed with ribbon forests.

\section{$\diamond \quad$ MIETHODS}

The locations of the project areas are shown in Table 1. These areas of inquiry were chosen because soapstone is a ultra-mafic metamorphic rock, a type of rock with limited distribution in the Tetons. Ultramafic bodies were mapped by the late geologist J. David Love (Love et al. 1992). While other Precambrian rocks may contain soapstone elsewhere in the Tetons, it is almost sure to be found in ultra-mafic rocks.

\begin{tabular}{|l|l|l|l|}
\hline Table 1. Project Area Summary. & Site Number & $\begin{array}{l}\text { Previously } \\
\text { Recorded } \\
\text { Cultural } \\
\text { Resources? }\end{array}$ \\
\hline \hline Place Name & Geology & $48 T E 529$ & $\begin{array}{l}\text { Aboriginal } \\
\text { soapstone } \\
\text { quarry }\end{array}$ \\
\hline Owl Creek & Layered gneiss & $\begin{array}{l}\text { Historic } \\
\text { asbestos mine) }\end{array}$ \\
\hline $\begin{array}{l}\text { Upper Berry } \\
\text { Creek }\end{array}$ & Ultramafic & 48 TE1255 \\
\hline $\begin{array}{l}\text { Rammel } \\
\text { Mountain }\end{array}$ & Augen gneiss & & \\
\hline $\begin{array}{l}\text { Bitch Creek } \\
\text { Narrows }\end{array}$ & Ultramafic & \\
\hline Bitch Creek & Ultramafic & \\
\hline $\begin{array}{l}\text { Columbine } \\
\text { Cascade }\end{array}$ & Ultramafic & \\
\hline Moran Canyon & Ultramafic & \\
\hline
\end{tabular}

Unofficial searches of the Cultural Records Office database in Laramie were performed for the project areas prior to beginning fieldwork. A search of the CRO database (conducted 11/22/02) searching Teton County for the keyword "quarry" revealed that only one soapstone quarry has been recorded. Site 48TE529 was recorded by C.M. Love in 1971, who called it the "most important steatite quarry in the northern Teton Range" (C.M. Love 1971). Unfortunately, neither site maps nor photographs accompany the site form, and narrative description is only two sentences long.

The CRO file search also revealed that, other than 48TE529, no prehistoric cultural sites have been recorded in the vicinity of other soapstone sources whose geology was mapped by J. D. Love (Love et al. 1992). Slim Lawrence's historic asbestos mine (48TE1255), is also a source of soapstone, but appears to lack a prehistoric component; it is discussed further in the SURVEY RESULTS section. The Rammel Mountain soapstone source is shown on Love's geologic map of the 
Tetons, but was never recorded as a prehistoric or historic cultural resource.

A total of 139 acres, surveyed at or near Class III standards (SHPO 2002), consists of 99 acres of linear survey both in GTNP and the Caribou-Targhee National Forest and about 40 acres of block survey in the Rammel Mountain area. The linear survey total is derived from multiplying the total number of miles walked (27.25) by $5280 \mathrm{ft} / \mathrm{mile}$ by a 30 foot wide survey corridor. The survey crew consisted of two professional archaeologists and three volunteers.

Prehistoric cultural resources were recorded in compliance with current State Historic Preservation Office standards. Cultural resources encountered during pedestrian surveys were located with GPS receivers. Individual artifacts and features were located with GPS receivers, photographed, and described.

Isolated finds were located on a USGS $7.5^{\circ}$ topographic map with a handheld GPS receiver, photographed, and the environmental context was recorded on Wyoming SHPO isolated find forms. The presence of two or more artifacts or features within $30 \mathrm{~m}$ of their nearest neighbor was considered a site. A thorough ground survey covered the site area; colored pin flags were placed to mark the location of each artifact and feature in a site. The locations of artifacts and sites were recorded with a GPS receiver and plotted on the appropriate USGS 7.5' topographic map using iGage (1999) All Topo Maps: Wyoming software. All pin flagged artifacts were recorded as to material type and general morphology (i.e., primary flake, core, biface, etc.) based on criteria outlined in Table 2. Time period definitions are in the same table.

A simplified Wyoming Cultural Properties Form was filled out for each site, and each site was plotted on the appropriate USGS 7.5' topographic map. The site setting, as well as tools, hafted bifaces, soapstone artifacts, and features were photographed. No subsurface testing was undertaken.

Sites were evaluated for National Register of Historic Places (NRHP) eligibility as either unevaluated or eligible. The rationale is that, given the brief nature of the field work, we were unable to spend enough time at sites to determine ineligibility. Also, most of these sites were in or near the trees, and past experience has shown that timber can easily conceal cultural resources.

\begin{tabular}{|c|c|}
\hline \multicolumn{2}{|c|}{ CHIPPED CRYPTOCRYSTALLINE STONE } \\
\hline $\begin{array}{l}\text { PRIMARY } \\
\text { FLAKE }\end{array}$ & $\begin{array}{l}\text { A complete flake with a single ventral } \\
\text { surface, a point of applied force, (i.e., } \\
\text { striking platform), and intact flake margins. } \\
\text { Flake margins are considered intact if the } \\
\text { distal end exhibits a hinge or feather } \\
\text { termination and if lateral breaks or snaps (if } \\
\text { present) do not interfere with accurate width. } \\
\text { It retains cortex on } 100 \text { to } 75 \% \text { of its dorsal } \\
\text { surface. }\end{array}$ \\
\hline $\begin{array}{l}\text { SECONDARY } \\
\text { FLAKE }\end{array}$ & $\begin{array}{l}\text { Same as above, retaining between } 75 \text { and } \\
1 \% \text { cortex on the dorsal surface. }\end{array}$ \\
\hline $\begin{array}{l}\text { TERTIARY } \\
\text { FLAKE }\end{array}$ & $\begin{array}{l}\text { Same as above, but no cortex on the dorsal } \\
\text { surface. }\end{array}$ \\
\hline DEBRIS & $\begin{array}{l}\text { Debitage lacking a ventral surface, point of } \\
\text { applied force, or intact flake margins. }\end{array}$ \\
\hline CORE & $\begin{array}{l}\text { Any nucleus of raw material which exhibits } \\
\text { the removal of two or more flakes of } \\
\text { sufficient size }(2-3 \mathrm{~cm}) \text { to have been useful } \\
\text { as flake tool blanks. }\end{array}$ \\
\hline $\begin{array}{l}\text { TESTED } \\
\text { COBBLE }\end{array}$ & $\begin{array}{l}\text { A piece of raw material having a minimum } \\
\text { number of flakes removed. The flake scars } \\
\text { are small }(2 \mathrm{~cm}) \text { and the flakes removed are } \\
\text { not judgmentally believed to have been } \\
\text { useful as tools (Ahler 1986:50). }\end{array}$ \\
\hline CHOPPER & $\begin{array}{l}\text { A cobble with at least one end exhibiting the } \\
\text { removal of flakes. The modified edge } \\
\text { usually has been dulled or blunted by } \\
\text { battering and use (Sanders 1995:14). }\end{array}$ \\
\hline $\begin{array}{l}\text { HAFTED } \\
\text { BIFACE }\end{array}$ & $\begin{array}{l}\text { Bifacially flaked implement with a pointed } \\
\text { distal end and basal modification (Chapman } \\
\text { 1977:413). Most hafted bifaces are } \\
\text { probably projectile points; larger ones may } \\
\text { have had other uses. }\end{array}$ \\
\hline BIFACE & $\begin{array}{l}\text { Chipped stone objects with flattened cross- } \\
\text { sections which exhibit bifacially directed } \\
\text { flake removals (Ahler 1986:54). }\end{array}$ \\
\hline$\overline{\text { DRILL }}$ & $\begin{array}{l}\text { Flakes or bifaces with narrow, elongated, } \\
\text { bifacially retouched projections. Projections } \\
\text { are generally at least } 1 \mathrm{~cm} \text { long and have } \\
\text { diamond-shaped cross-sections. }\end{array}$ \\
\hline $\begin{array}{l}\text { RETOUCHED } \\
\text { FLAKE }\end{array}$ & $\begin{array}{l}\text { A flake with a modified edge where a series } \\
\text { of flakes were intentionally removed. The } \\
\text { retouch may extend across the entire surface } \\
\text { of one side of the flake. Includes items } \\
\text { commonly known as gravers, scrapers, and } \\
\text { unifaces. }\end{array}$ \\
\hline $\begin{array}{l}\text { UTILIZED } \\
\text { FLAKE }\end{array}$ & $\begin{array}{l}\text { A flake showing a regular series of edge } \\
\text { modifications typically due only to use. The } \\
\text { edge modifications is generally limited to the } \\
\text { removal of microflakes less than } 2 \mathrm{~mm} \text { in } \\
\text { length. }\end{array}$ \\
\hline \multicolumn{2}{|c|}{ GROUNDSTONE } \\
\hline GROUNDSTONE & $\begin{array}{l}\text { Stone artifacts manufactured by pecking } \\
\text { and abrading. They are used for refining } \\
\text { raw materials from the environment into } \\
\text { digestible or utilitarian products; i.e., } \\
\text { manos and metates (Shepherd 1992). }\end{array}$ \\
\hline HAMMERSTONE & $\begin{array}{l}\text { A cobble with evidence of non-random } \\
\text { battering generally located on one or more } \\
\text { ends. }\end{array}$ \\
\hline
\end{tabular}




\begin{tabular}{|c|c|}
\hline \multicolumn{2}{|c|}{ SOAPSTONE (from Adams 1992) } \\
\hline WORKED PIECE & $\begin{array}{l}\text { Any piece of soapstone with manufacturing } \\
\text { marks such as pecks, grooves, hatchet } \\
\text { marks. }\end{array}$ \\
\hline PREFORM & $\begin{array}{l}\text { Although recognizable in shape, a preform } \\
\text { has not been carved out to the point of } \\
\text { functionality. }\end{array}$ \\
\hline BOWL & $\begin{array}{l}\text { A completed piece that is generally } \\
\text { flowerpot-shaped and holds between } 1 \text { and } 2 \\
\text { liters }\end{array}$ \\
\hline $\begin{array}{l}\text { MANUFACTURIN } \\
\text { G MARKS }\end{array}$ & $\begin{array}{l}\text { Pecks: small pits made by hitting soapstone } \\
\text { with pointy bone, antler or stone tools.Gouges: } \\
\text { continuous application of pressure on a sharp } \\
\text { tool results in long manufacturing marks. Metal } \\
\text { Tools make regular, parallel and consistent } \\
\text { marks.Percussion produces pecks, gouges, and } \\
\text { hatchet marks. Abrasion produces striae and } \\
\text { polish. }\end{array}$ \\
\hline \multicolumn{2}{|r|}{ TIME PERIODS } \\
\hline Historic & $\begin{array}{l}\text { In Wyoming, generally after } 1805 . \\
\text { European trade goods begin to dominate } \\
\text { aboriginal society. }\end{array}$ \\
\hline Protohistoric & $\begin{array}{l}\text { The short period between the arrival of the } \\
\text { first trade goods and horses (ca 1650) and } \\
\text { the arrival of Anglo explorers (ca 1805). }\end{array}$ \\
\hline Prehistoric & $\begin{array}{l}\text { The } 12,000 \text { or so years of human occupation } \\
\text { of North America before ca } 1492 \text { A.D. The } \\
\text { prehistoric is further divided into the } \\
\text { Paleoindian period (ca } 12000 \text { to } 7500 \mathrm{BP} \text { ), } \\
\text { the Archaic ( } 7500 \text { to } 1500 \mathrm{BP} \text { ) and the Late } \\
\text { Prehistoric ( } 1500 \text { to ca } 1650 \mathrm{AD} \text { ). }\end{array}$ \\
\hline
\end{tabular}

All field notes, photographs, maps, etc., are housed at the Office of the Wyoming State Archaeologist in Laramie, Wyoming.

Copies of this report and completed site forms, maps and photographs were submitted to the SHPO Cultural Records Office, the National Park Service, and the Caribou-Targhee National Forest.

\section{SOAPSTONE GEOLOGY}

Soapstone is the common name for a rock composed chiefly of the mineral talc (Table 3). Talc is one of the softest of all the minerals; it defines the low end of the 10-step Mohs hardness scale. You can scratch a piece of talc with your fingernail. In the field it is bluish or greenish or greyish; finished artifacts are often black. The powdered rock feels soapy when you rub it between your fingers.

\begin{tabular}{|l|l|}
\hline Table 3. Attributes of Soapstone. \\
\hline Rock Type & $\begin{array}{l}\text { Metamorphosed dolomite or ultramafic } \\
\text { rock. }\end{array}$ \\
\hline Age of Rock & $\begin{array}{l}\text { Restricted to Precambrian rocks in } \\
\text { Wyoming, >2.5 billion years old }\end{array}$ \\
\hline Mineral & Talc \\
\hline Hardness & $\begin{array}{l}\text { Defines 1 on the Mohs scale. Can be } \\
\text { scratched with a fingernail. }\end{array}$ \\
\hline Texture & Powdered rock feels soapy. \\
\hline Color & Bluish, greyish, or greenish. \\
\hline Habitat & $\begin{array}{l}\text { Saddles, passes, valleys; does not form } \\
\text { ridges or prominent outcrops. }\end{array}$ \\
\hline Chemistry & $\begin{array}{l}\left.\text { Mg } 6 \text { [Si }{ }_{8} \mathrm{O}_{20} \text { ] (OH) }\right)_{4} \text { i.e., a magnesium } \\
\text { silicate }\end{array}$ \\
\hline Fall-off rate & $\begin{array}{l}\text { Sharp, does not survive long in fluvial } \\
\text { or glacial environments. }\end{array}$ \\
\hline Also known as: & $\begin{array}{l}\text { Steatite. Soapstone and steatite are not } \\
\text { Catlinite. }\end{array}$ \\
\hline
\end{tabular}

Under the right temperature and pressure conditions, a magnesium silicate like dolomite metamorphoses into steatite or soapstone (Harris 1995b). It occurs in small deposits in Wyoming's mountains in metamorphic Precambrian rock that is older than 2.5 billion years.

Soapstone does not occur in predictable places like chert and quartzite. For example, the Paleozoic and Mesozoic-aged formations that contain cherts and quartzites are almost invariably ridge-forming rocks. If you see a ridge of Dakota sandstone, you know that if you walk below the outcrop you will eventually find the Morrison Formation and good cherts and quartzites. Eocene cherts are found in desert basins around the margins of the extinct Lake Gosiute. With experience, it is easy to predict where chert will occur, even without formal geological training.

On the other hand, knowing that soapstone occurs in Archean metamorphic rocks adds absolutely no predictability to its occurrence. Soapstone sources donot form ledges, do not form ridges, and do not occur above or below distinctive formations. However, many prehistorically utilized soapstone sources in Wyoming seem to be close to the contact between Precambrian and younger sedimentary rocks.

When you carve soapstone the result is talcum powder. Big tools like choppers, picks, hatchets, and chisels produce some macroscopic "debitage", but in 
my experience it weathers so fast that it is almost impossible to see after a few years on the ground.

\section{PREVIOUS RESEARCH}

In the literature, the amount of consideration accorded to steatite artifacts by researchers is often overshadowed by chipped stone artifacts. Yet the distribution of prehistoric and historic steatite artifacts is nearly global. Steatite is found on all six inhabited continents and many of the continental islands. The following is condensed from Adams (1992).

\section{A Few Early Accounts in Western North America}

In their 1804-1806 journey, Lewis and Clark note that the Lemhi Shoshone's cookware "consist of pots in the form of a jar made either out of earth or a soft white stone which becomes black and very hard by burning" (Thwaites 1904:19). They write that the soft rock was found near the Three Forks of the Missouri at the confluence of the Madison and Gallatin rivers (Thwaites 1904:19). They were most likely referring to soapstone, which is commercially mined in this area today (Wells 1974).

In 1805, the trader Laroque noted a carved stone cooking vessel:

I traded eight beavers with the Snake Indians in whose possessions I saw a Kettle or Pot hewn out of solid stone. It was about $11 / 2$ " thick and contained 6 or 8 quarts; it had been made with no other instrument but a piece of iron (Laroque in Wedel 1954:407)

This earliest reference contains the germs of three topics that continue to be of interest. First, a chronological marker: the object was in use at the time of contact. Second, the probable method of manufacture: the vessel was carved with an iron tool. Third, the cultural identity of the users was noted.

In an 1881 report, P.W. Norris, the superintendent of Yellowstone National Park, mentions high country steatite bowls found in the Park. Given that there are prehistorically utilized soapstone sources on the north, east, and south sides of the park, it is not surprising that prehistoric steatite artifacts have been found in this area.

\section{RECENT RESEARCH}

J. David Love (Love and Christiansen 1985; Love et al. 1992) mapped the location of ultramafic rocks across Wyoming and in the Tetons. When Love (et al. 1992) mapped the geology of the Teton Range, he located five areas of ultramafic rock (Table 1). At least two of these sources have signs of aboriginal utilization (J.D. Love, personal communication 2002). Dave Love's son Charlie visited one of the aboriginally utilized steatite source in 1971. The locale was given a Smithsonian site number (48TE529; Table 1).

Frison (1982) details the distribution of aboriginally-utilized quarries and the manufacture of artifacts and examines some of the finished vessels. The aboriginal quarrying and manufacturing that Frison (1982:279) describes involved both pecking and gouging out vessel preforms while the blank was part of the outcrop. After the preform was roughed out, it was sometimes transported to another area for more shaping. In one case, a preform weighing 52 kilograms was transported two kilometers away from the quarry (Frison 1982:279).

Vessels do not appear to be randomly distributed across Wyoming (Marceau 1982 n.d.:22-25). However, it is not clear whether the vessel distribution is determined by the distribution of the quarries (Love 1972), or by patterns of human movement and subsistence strategies, or both. The greatest concentration of steatite vessels at a single site occurs at the Lawrence site on the shores of Jackson Lake (Wright 1984:54).

Little is known about the age of steatite vessels. Some vessels (or fragments), such as those from the River Bend Site (McKee 1988) or the Natural Corrals site (Larson 1965), were found in Protohistoric sites associated with Shoshone. The organic residue from the interior of a steatite bowl was dated to $\mathrm{AD} 1848$ by accelerator mass spectroscopy (Adams 1992, Adams and Daniels 1995). The age of vessel manufacture is tied to questions about the ethnic affiliation of the vessel manufacturers. Wedel (1954) first raised the question of ethnic affiliation of steatite vessels and Shoshonean pottery, and concluded that the "ethnohistorical data indicate the steatite-working, like pottery making, was probably carried on by Shoshonean groups into the 19th century" (Wedel 1954: 407). Marceau (1982 n.d.: 81), citing numerous ethnographic and archaeological references to steatite artifacts and ceramics, disagreed: "neither ethnographic, ethnohistoric, nor archaeological data support an association between steatite and the 
Shoshone." Frison (1982) concluded that steatite vessels are probably Late Prehistoric to Historic in age, and probably used by Shoshonean groups.

The most recent research on steatite emphasizes the range of artifact variation and attempts to explain how these were made and distributed (Frison 1982; Marceau 1982; Adams 2003b). Tools such as accelerator mass spectrometry dating, X-ray fluorescence (Adams 1992), $X$-ray diffraction (Adams 2002a), and gas chromatography mass spectroscopy (Malainey 2003) now permit research on questions of the use, transport, and dating of steatite artifacts.

\section{$\downarrow \quad$ SURVEY RESULTS}

The first two site descriptions are updates of previously recorded sites in Grand Teton National Park. The remaining six sites occur in the Caribou-Targhee National Forest and are described here for the first time. Three of these new sites are exclusively prehistoric and three have both historic and prehistoric artifacts.

\section{Grand Teton National Park Sites}

The two sites recorded in Grand Teton National Park are described below.

\section{SITE: 48TE1255 (Figure 2).}

DESCRIPTION: 48TE1255 is an asbestos mine on the northern flank of Forellen Peak, above Berry Creek in Grand Teton National Park. Site size is $90 \mathrm{~m}$ NBS by 40 $\mathrm{m} \mathrm{E}-\mathrm{W}$, for an area of about $2830 \mathrm{~m} 5$. The mine adit opening is at an altitude of 7940 feet above sea level.

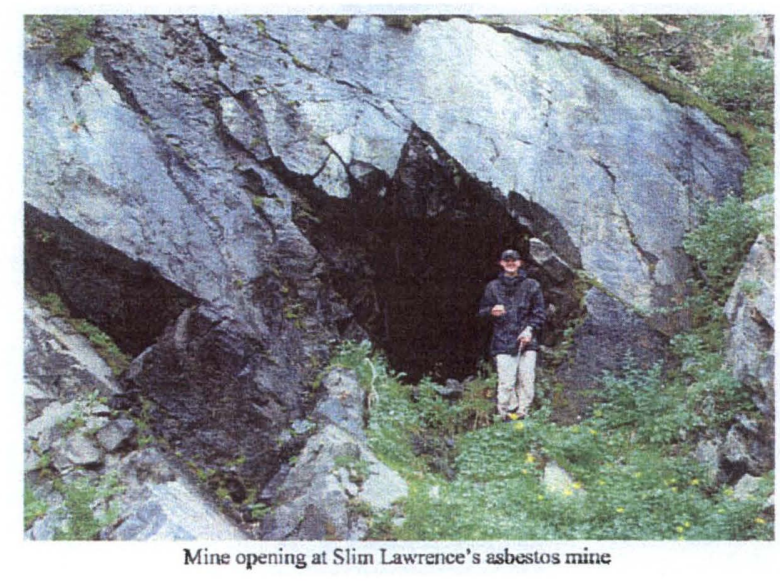

Figure 2. Photographs of 48TE1255.
This is what remains of Slim Lawrence's asbestos mine. Green chrysotile asbestos (Harris 1995a) was observed in small quantities in the talus below the mine opening, and there is an outcrop of long-fiber $(>5 \mathrm{~cm})$ white asbestos, about $15 \mathrm{~cm}$ thick by $2 \mathrm{~m}$ tall in the exposed wall near the opening.

The site was originally recorded in 1990 by Melissa Connor, who did not visit the site, but relied on a backcountry ranger's description. The NPS/OWSA team visited the site on $8 / 4 / 03$ and the following description is based on that visit. The site consists of mine adit (a horizontal shaft) and a talus cone at least $60 \mathrm{~m}$ long by $>30 \mathrm{~m}$ wide at the base. The site is on a steep slope $\left(45^{\circ}\right.$ at the mine opening). The talus originates at the mine opening and tumbles down 25 vertical meters, almost reaching the valley floor. The talus cone was created by mining the outcrop and discarding the least desirable rocks down slope. The talus slope consists of dark grey ultramafic rocks including bowl sized and bigger chunks of soapstone. Numerous large pieces of high quality soapstone were observed. The mine represents a considerable amount of work. Many hundreds of tons of rock were moved by Lawrence and dumped down the slope.

Above the talus slope is a flat spot about $20 \mathrm{~m}$ $\mathrm{N}-\mathrm{S}$ by $40 \mathrm{~m} \mathrm{E}-\mathrm{W}$ chiseled out of the solid rock slope. The back wall of the flat spot has a mine adit. The adit's opening is about $2.5 \mathrm{~m}$ above the flat spot. The adit goes horizontally back (south) in to the hillside. The adit is about $20 \mathrm{~m}$ long and about $2 \mathrm{~m}$ in diameter. During the site visit on $8 / 4 / 03$, there was a steady trickle of water pouring out of the mine. The flat spot is now a thriving riparian zone.

No historic features were observed below the mine, although experience suggests that there should be a camp/cabin in the valley below. There are faint traces of trails on either side of the mine opening, but neither could be followed to the valley floor. The only observed artifact was a twisted length of 2 inch pipe. Connor (1990:4), relying on a backcountry ranger's description, writes that "larger equipment associated with mining is scattered throughout the area."

The mine dates to no later than the 1920 s. Harris (1995a:7) states that "small amounts of asbestos were produced prior to 1921" in his report on the economic geology of asbestos and serpentine deposits in Wyoming. In their section on asbestos in Wyoming, Ladoo and Myers (1951:47) note that asbestos is mined "near Berry Creek in Lincoln County [sic], on the north side of Forellen Peak, 35 miles from the nearest shipping point at Ashton, Idaho." Given that Teton County was 
established by the Wyoming State Legislature in 1920 (Larson 1965:453), it seems that Ladoo and Myers were using old data.

We found no traces of aboriginal soapstone quarrying near the opening or on the talus slope below. We did not explore the steep terrain above the mine because rain had made the $45^{\circ}$ slope too slippery for safe surveying. Traces of aboriginal quarrying are defined as peck marks or a series of axe/hatchet marks surrounding the place where bowl preforms were detached. Peck marks imply Prehistoric use of the soapstone source. Hatchet marks imply Protohistoric or Historic use by people seeking to detach large chunks for bowl manufacture (Table 2). I suspect that any trace of aboriginal use has been obliterated by mining.

TESTING: No testing was performed.

NATIONAL REGISTER STATUS: In 1990 Connor wrote that there was insufficient data to evaluate the site's eligibility. Grand Teton National Park archeologist Jaquelin St Clair (personal communication 8/04/03), said that the site should be considered eligible for nomination to the National Register of Historic places during a site visit. The site is a reasonably intact example of $1920 \mathrm{~s}$ mining practices. It can be associated with a person important to local history. It is also a rich source of soapstone that may have been used prehistorically. Because of its location in a national park, it is reasonably well preserved with excellent feeling of association. For these reasons the site is considered to be eligible under Criteria B and D.

IMPACTS: Other than the threat of mineral sample collection, impacts are unknown.

RECOMMENDATIONS: No further work is recommended.

SITE: 48TE529 (Figure 3).

DESCRIPTION: We confirmed that there is a large amount of soapstone on Owl Peak in Grand Teton National Park, but were unable to locate its bedrock source. The Owl Peak source occurs in a rugged canyon following the trace of the Forellen Fault (Love et al. 1992). The west side of the canyon is steeply inclined Paleozoic sedimentary limestone, while the east side of the canyon is Precambrian gneiss. This is a steep, dynamic environment, and rocks were shifting underfoot with every step across boulders, talus and scree.

Dave Love's son Charlie visited this aboriginal utilized steatite source in 1971 and filled out a site form and the locale was given a Smithsonian site number (48TE529), but no maps accompany the site form and the written site description is one sentence long: "Narrow ridge of steatite", with the qualifier that this is the "most important steatite quarry in the northern Teton Range" (Love 1971).

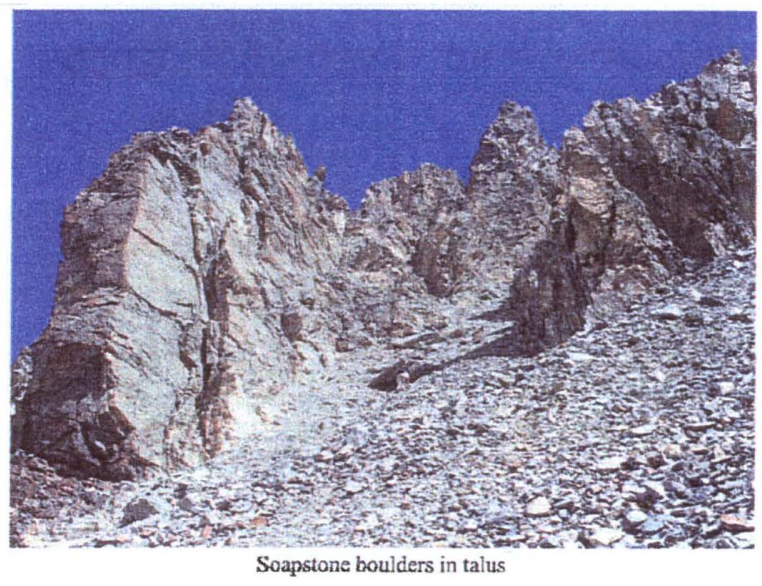

Figure 3. Photograph of 48TE529

To further confound the matter, there are two contrasting legal locations for the site. One location is Charlie's, the other is from SHPO. We searched for the asbestos mine rather than the SHPO location because in my experience there is always soapstone at an asbestos outcrop, while the reverse is rarely true.

We did not reach the primary soapstone source described by Charlie Love. The "narrow ledge of soapstone" that Charlie Love (1972) describes was not visible and may have occurred a couple hundred meters east and above us.

Access to the asbestos mine on the upper spur of Owl Peak is best attained from some other approach than the one we took. Unstable talus slopes prevented us from climbing higher than 8800 feet, while the asbestos mine plots out a little below 9200 feet on Love's (et al. 1992) map. We did see tons of soapstone in the form of boulders up to $2 \mathrm{~m}$ on a side. The boulders occurred in a cirque-like area at the heads of two unnamed drainages that follow the trace of the Forellen Fault. We climbed up the cirque to about 9400 feet and saw soapstone, but no traces of aboriginal soapstone use.

TESTING: No testing was performed.

NATIONAL REGISTER STATUS: Unevaluated until C.M. Love's site is relocated and visited. More work needs to be done to resolve the discrepancy between the Love asbestos mine location and the SHPO site location. IMPACTS: Impacts are unknown.

RECOMMENDATIONS: More work is recommended. 


\section{Caribou-Targhee National Forest Sites}

The following six sites are on the west side of the Teton Range on public land administered by the Caribou-Targhee National Forest. The sites occur in and near the Jedediah Smith Wilderness. They were located and recorded as a direct result of the UW-NPS grant.

\section{SITE: 48TE1643 B Rammel 1 (Figure 4).}

DESCRIPTION: Site size is $7 \mathrm{~m}$ in diameter for an area of $154 \mathrm{~m} 5$. The site is in the Jedediah Smith Wilderness of the Caribou-Targhee National Forest on the west side of the Teton Range. The site occurs on both sides of a trail that climbs a flank of Rammel Mountain. This trail sees horse, pedestrian, and snowmobile use. The site is on an open ridge line, but there are scattered whitebark pines, sub-alpine fir, and Engelmann spruce within a few tens of meters on either side of the trail where the ground begins to drop steeply.

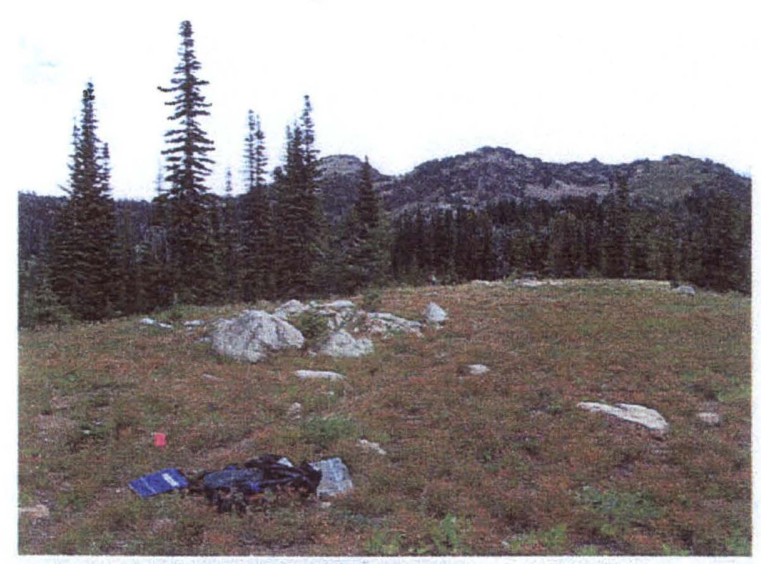

48TE1643 site photo

Figure 4.

The site consists of a small lithic scatter with a broken, Late Prehistoric, unnotched projectile point made from obsidian. The tip of the 14 by 13 by $2.5 \mathrm{~mm}$ thick projectile point broke off before it could be finished by notching the sides. The point was not collected, but left under a pile of four cobbles less than one meter from its findspot. A dark grey basalt primary flake and three pieces of ignimbrite debitage (one each: secondary, tertiary, and debris) were also recorded.

The only modern artifact was the ignition key to a Polaris snowmobile.

TESTING: No testing was performed.

NATIONAL REGISTER STATUS: This small lithic scatter contains only one diagnostic artifact. The site occurs where there is negligible Holocene deposition. Recording has exhausted the site's information potential.
For these reasons, the site is considered to be ineligible for National Register nomination.

IMPACTS: Other than the threat of collection by looters, impacts are unknown.

RECOMMENDATIONS: No further work is recommended.

SITE: 48TE1644 B Rammel 2 (Figure 5).

DESCRIPTION: The site is in the Jedediah Smith Wilderness of the Caribou-Targhee National Forest on the west side of the Teton Range. Site size is $15 \mathrm{~m} \mathrm{~N}$-S by $45 \mathrm{~m} \mathrm{E}-\mathrm{W}$ for an area of $565 \mathrm{~m} 5$. The site occurs on both sides of a trail that climbs a flank of Rammel Mountain. This trail sees horse, pedestrian and snowmobile use. The site is on the open ridge line, but there are scattered whitebark pines, sub-alpine fir, and Engelmann spruce within a few tens of meters on either side of the trail where the ground begins to drop steeply. The site is roughly $500 \mathrm{~m}$ east of $48 \mathrm{TE} 1643$.

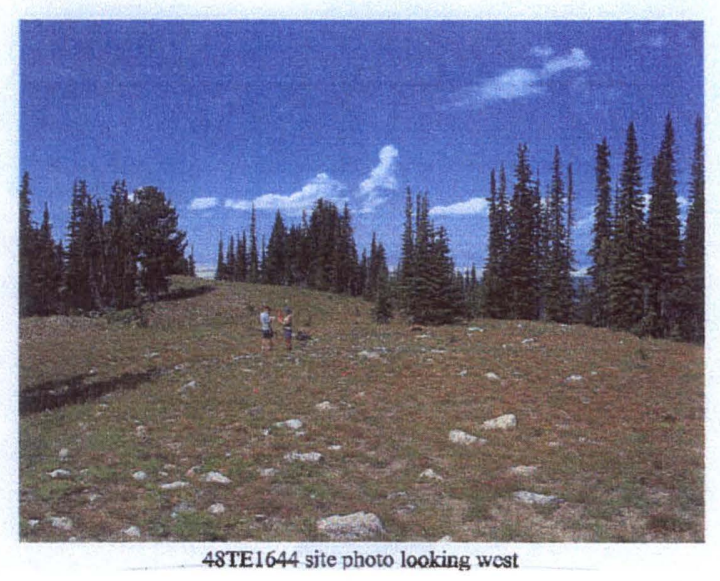

Figure 5.

The site consists of a light lithic scatter of obsidian, ignimbrite, chert, chalcedony, and two small pieces of soapstone debitage. Surface artifacts are summarized in Table 4.

\begin{tabular}{|c|c|c|c|c|c|}
\hline $\begin{array}{c}\text { Material } \\
\text { Type }\end{array}$ & Primary & Secondary & Tertiary & Debris & Other \\
\hline Ignimbrite & 1 & & 1 & 5 & \\
\hline Obsidian & & 1 & 4 & & \\
\hline Grey Chert & & & 2 & & \\
\hline Chalcedony & & & 1 & & \\
\hline Soapstone & & & & & $\begin{array}{l}2 \text { small } \\
\text { pieces }\end{array}$ \\
\hline
\end{tabular}


The two small pieces of soapstone are less than $10 \mathrm{~cm}$ long and do not exhibit any manufacturing marks (Figure 6), yet experience suggests that they are not naturally occurring. They may be soapstone "debitage" left over from bowl manufacture. One piece was found within $20 \mathrm{~cm}$ of a chert flake. Soapstone weathers rapidly, and on a windy ridge frequented by snowmobiles in the winter, horses and pedestrians in the summer, the combination of natural erosion and human impact may have removed the faint traces of manufacture on this softest of rocks.

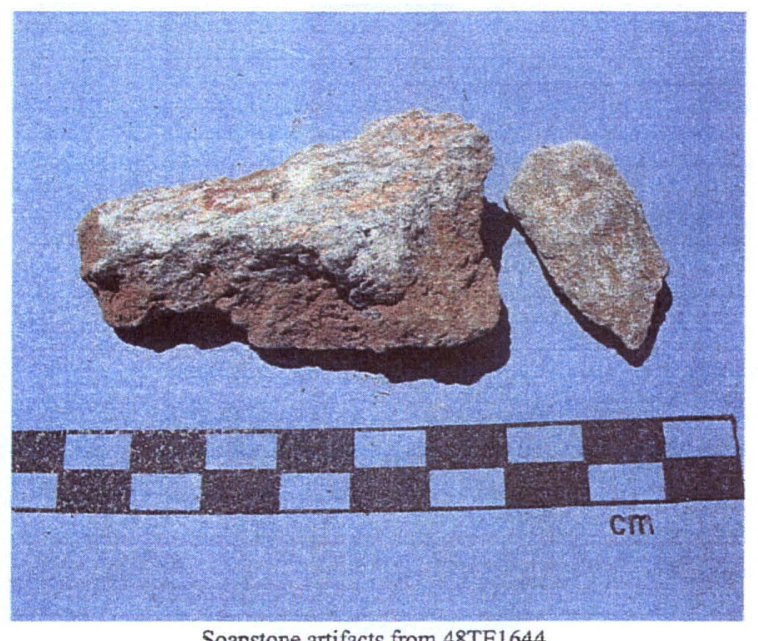

Figure 6. Photograph of 48TE1644

TESTING: No testing was performed.

NATIONAL REGISTER STATUS: This site is unevaluated. Lithic scatters with soapstone "debitage" are extremely rare. I would like to re-examine this site and the surrounding country before considering it to be ineligible.

IMPACTS: Other than the threat of collection by looters, impacts are unknown.

RECOMMENDATIONS: Further work is recommended.

SITE: 48TE1645 B Rammel 3 (Figure 7).

DESCRIPTION: The site is in the Jedediah Smith Wilderness of the Caribou-Targhee National Forest on the west side of the Teton Range. The site is $17 \mathrm{~m}$ in diameter for an area of $227 \mathrm{~m}^{5}$. The site consists of lithic debitage, soapstone (probably related to the historic mine) and historic artifacts and features (Table 5). This site is about $75 \mathrm{~m}$ west of the Rammel Mountain soapstone quarry.

The soapstone debris found at this site differs from that at the previous site (48TE1644). Soapstone debris at this site consists of fist-size and larger rocks with sharp edges, indicating recent mining, while the soapstone at $48 \mathrm{TE} 1644$ is much smaller, much thinner, and more likely to have resulted from bowl manufacture.

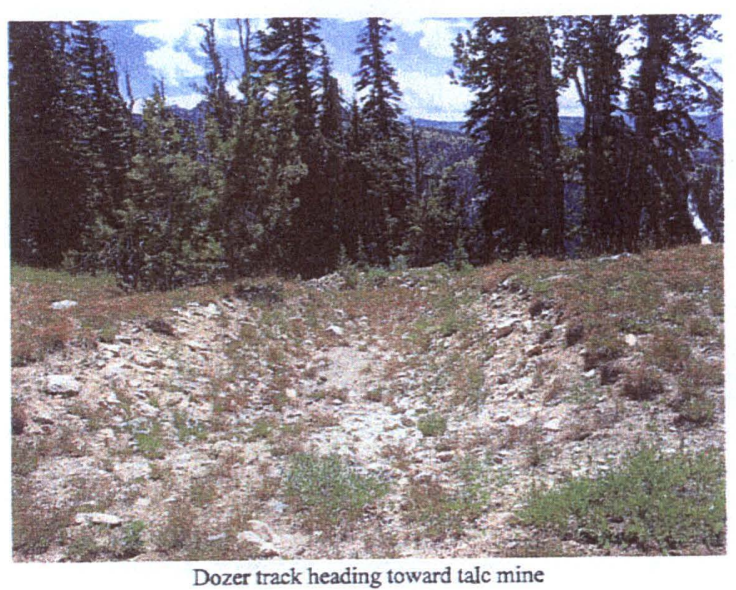

Figure 7. Photograph of 48TE1645

\begin{tabular}{|c|c|c|c|c|}
\hline $\begin{array}{l}\text { Material } \\
\text { Type }\end{array}$ & Secondary & Tertiary & Debris & Other \\
\hline Ignimbrite & 2 & 3 & 3 & \\
\hline Obsidian & & 1 & 1 & \\
\hline Soapstone & & & & $\begin{array}{l}\text { debris from } \\
\text { historic } \\
\text { mining }\end{array}$ \\
\hline
\end{tabular}

The two historic features are linear scars left by a bulldozer that lead toward 49TE1646 - the Rammel Mountain Soapstone Quarry. Both are over $30 \mathrm{~m}$ long and up to $1 \mathrm{~m}$ deep. Two explanations for the dozer tracks are possible: First, miners were using the dozer to look for more soapstone; second, they were blading access to the soapstone body to facilitate its removal. Historic artifacts consist of post-1950s steel and glass fragments.

TESTING: No testing was performed.

NATIONAL REGISTER STATUS: This site is unevaluated. Lithic scatters with soapstone "debitage" are extremely rare. I would like to re-visit this before I say that it is ineligible.

IMPACTS: Other than the threat of collection by looters, no impacts are known.

RECOMMENDATIONS: More work is recommended.

SITE: 48TE1646 B Rammel Mountain Indian Soapstone Quarry (Figure 8). 
DESCRIIPTION: The site is in the Jedediah Smith Wilderness of the Caribou-Targhee National Forest on the west side of the Teton Range. The site is an aboriginal soapstone quarry that has been almost completely obliterated by historic talc mining. Site size is $40 \mathrm{~m}$ NBS by $8 \mathrm{~m} \mathrm{E}$-W for an area of $250 \mathrm{~m} 5$.

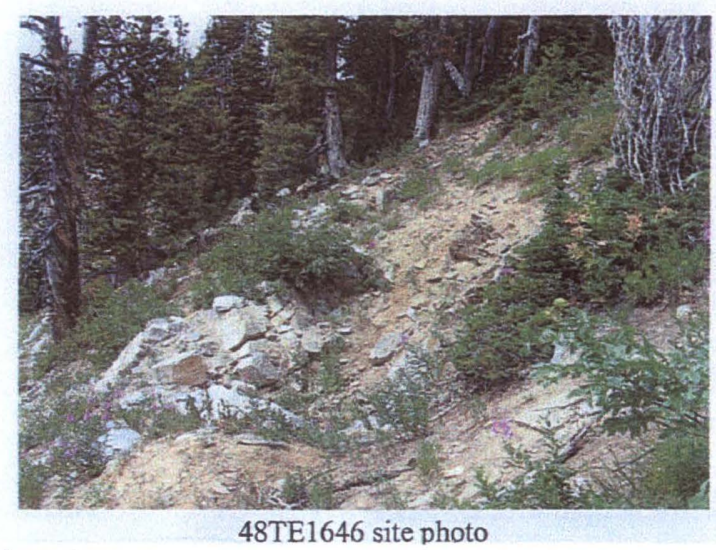

Figure 8.

The site was visited by J.D. Love, C.M. Love, and G.C. Frison in 1970; however, they did not formally record the site. The only record I could track down is what J.D. Love wrote in a precise hand, on the back of a photographic slide: "Rammel Mountain Indian soapstone quarry on high ridge $\mathrm{N}$. of Badger Creek, W. side of Teton Range, Teton Co., Wyo. Note lichen on pedestal. Rock is Precambrian talc. J.D. Love $9 / / 70$." On the other side, in a different hand, in blue ink is : "Pedestal is at the base of a carved stone bowl after the vessel itself was removed."

There are at least four modern mining pits that follow a 2-3 $\mathrm{m}$ wide soapstone vein at a 330-320 degree bearing. There is no asbestos at this mine, just talc and soapstone. Three of the mining pits have been dynamited and no traces of aboriginal quarrying were observed. At the lowest pit, a few traces of aboriginal use remain. Evidence of aboriginal quarrying is defined as peck marks (made by stone tools) or axe/hatchet marks. Peck marks imply Prehistoric use of the soapstone source. Hatchet marks imply Protohistoric or Historic use by people seeking to detach large chunks for bowl manufacture.

Pit 1 is the lowest of the pits. It measures 10 by 3 by $2 \mathrm{~m}$ deep. It contains traces of aboriginal use as well as historic mining. There are peck marks on a steatite outcrop near the original ground surface. There are hatchet scars where a bowl preform may have been detached (Figure 9). The historic mining traces consists of the pit itself, in addition to three $5 \mathrm{~cm}$ diameter by as much as $60 \mathrm{~cm}$ deep bore holes drilled into the steatite for shooting dynamite, and a number of historic graffiti. The Nichols family seems to have visited the site often. Janet Nichols, RMN, and $M N$ signed in three times on $7 / 7 / 73$, $\mathrm{KN}$ and $\mathrm{AMN}$ signed in on $7 / 29 / 74$, and Bud carved his name in 1984. If the number of times they signed in is any indication of their interest, the Nichols family might be good folks to contact about the presence of soapstone bowls in the area.

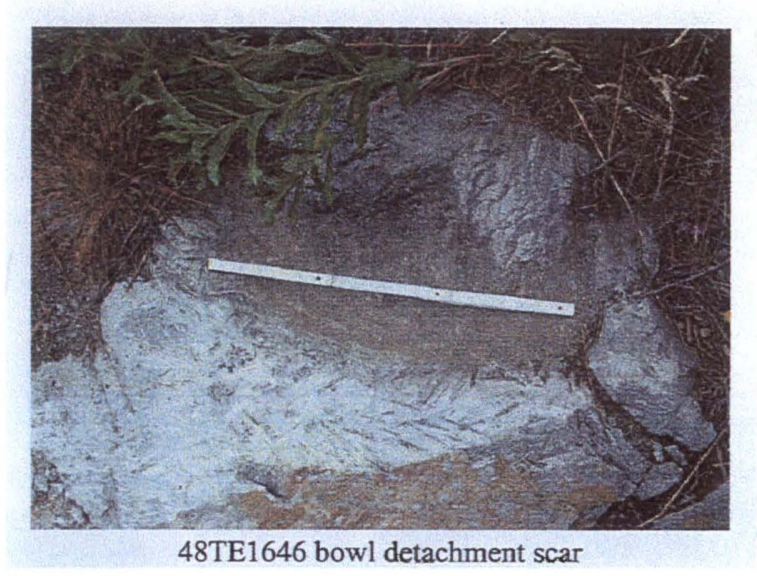

Figure 9.

The other pits are devoid of graffiti, bore holes, or aboriginal quarrying marks. Pit 2 exposes a wall of iron-stained soapstone about $4 \mathrm{~m}$ long by $1.5 \mathrm{~m}$ high. The pit is oriented at a bearing of 320 degrees.

Pit 3 is the largest of the four pits. It is about 15 $\mathrm{m}$ long by $4 \mathrm{~m}$ wide by $1.5 \mathrm{~m}$ deep. No traces of aboriginal or modern mining practices remain. The pit is oriented at a bearing of 330 degrees.

Pit 4 is almost contiguous with Pit \#3. The soapstone in this pit is a little more schisty than the other pits. There is an obvious contact with a non-steatific rock on the west wall of the pit.

Below the mine, soapstone boulders, cobbles and detritus occur for a few hundred feet. No preforms, bowls, or other aboriginal artifacts were observed in a fairly intense survey. However, Frison states (personal communication 8/13/03) that a large block of soapstone with an attached bowl preform lies in the Badger Creek valley, many hundreds of vertical feet below the quarry. This is the same preform shown in Love's 1970 slide. It was not relocated in 2003 .

INTERPRETATION: Given that there are prehistoric sites with soapstone and chipped stone artifacts nearby, and that peck marks are still visible in Pit \#1, I think it is safe to say that this source was used by Native Americans 
in Prehistoric and Protohistoric times. EuroAmericans mined the talc vein in the Historic past. As is common elsewhere with outcrops of high quality stone, such as chert, obsidian, ocher, and soapstone, that are known to have been important to prehistoric people, procurement and utilization continues into the present.

Frison (personal communication 1991) said that soapstone was considered by old time miners to be an indicator of gold. In 1950, high grade steatite, already ground fine enough to pass through a \#200 mesh screen, was selling for $\$ 10$ a ton (Ladoo and Myers 1951: 541). At that price, the Rammel Mountain soapstone source would have returned a few hundred dollars at most.

TESTING: No testing was performed.

NATIONAL REGISTER STATUS: Although the aboriginal component of the soapstone quarry has been almost obliterated by more recent workings, there is still information potential in what remains. For this reason it is unevaluated.

IMPACTS: Other than the threat of collection by looters, no impacts are known.

RECOMMENDATIONS: More work is recommended. Apparently, we did not descend the slope far enough to find the bowl preform attached to a soapstone slab that Love and Frison photographed. This piece needs to be examined to see if the manufacturing marks are prehistoric (peck marks) or historic (hatchet cuts).

SITE: 48TE1647 B Rammel Amble Ding Dong Site (Figure 10).

DESCRIPTION: The site is in the Jedediah Smith Wilderness of the Caribou-Targhee National Forest on the west side of the Teton Range. It is located in an Engelmann spruce and sub-alpine fir forest immediately north of a small spring-fed creek. Monkeyflower, sedges, and sorrel hug both sides of the creek. Large granitic boulders dot the landscape. There is a large amount of barren ground in this drainage, suggesting a dynamic environment. The site is on ground that slopes westsouthwest at $15^{\circ}$. It is a small site, only $9 \mathrm{~m}$ in diameter.

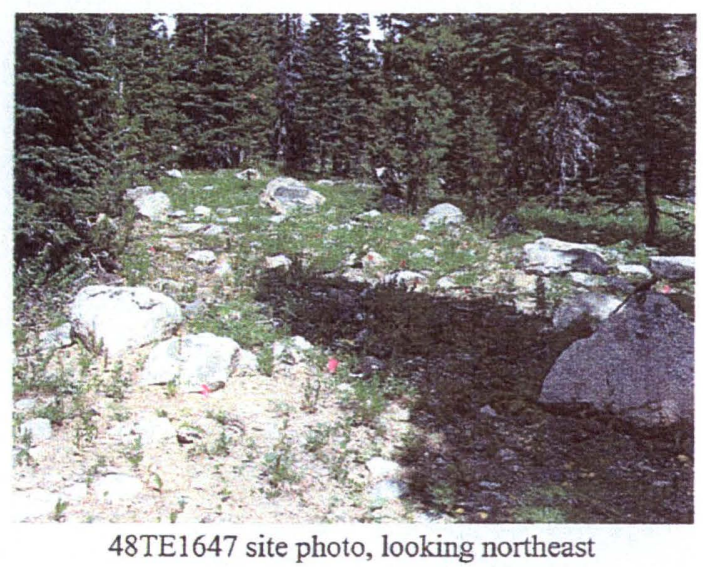

Figure 10.
The site consists of two broken soapstone bowl preforms, a broken soapstone bowl, and seven pieces of obsidian. Surface artifacts are summarized in Table 6.

\begin{tabular}{|l|l|l|l|l|l|}
\hline \hline $\begin{array}{l}\text { Table 6. Surface Arrifact } \\
\text { Mypententory, 48TEl } \\
\text { Type }\end{array}$ & Primary & Secondary & Tertiary & Debris & Other \\
\hline Obsidian & 1 & 1 & 1 & 3 & core \\
\hline Soapstone & & & $\begin{array}{l}2 \text { broken } \\
\text { bowl } \\
\text { preforms } \\
\text { and one } \\
\text { broken } \\
\text { bowl in 5 } \\
\text { pieces }\end{array}$ \\
\hline
\end{tabular}

Both preforms and the fragmentary bowl were found in a 7 meter diameter area. All five pieces of the broken bowl were found within a $0.75 \mathrm{~m}$ diameter area.

Preform \#1 is a broken soapstone bowl preform (Figure 11). It is $20 \mathrm{~cm}$ tall. The outside diameter is 19 by roughly $16 \mathrm{~cm}$. The inside diameter is 15.5 by roughly $11.5 \mathrm{~cm}$. The maximum excavated depth is $8 \mathrm{~cm}$. It is a classic (Frison 1982; Adams 1992) flowerpot-shaped vessel with a flanged base. The base diameter is 14 by $12 \mathrm{~cm}$, the flange is about $2 \mathrm{~cm}$ high. All the manufacturing marks left on the bowl are consistent with manufacture by stone tools. The interior base has been pecked, while the interior walls were gouged and chopped by a tool with an irregular working edge. The exterior was chopped circumferentially rather than longitudinally. The manufacturing marks are about $1 \mathrm{~cm}$ across by $0.7 \mathrm{~cm}$ long.

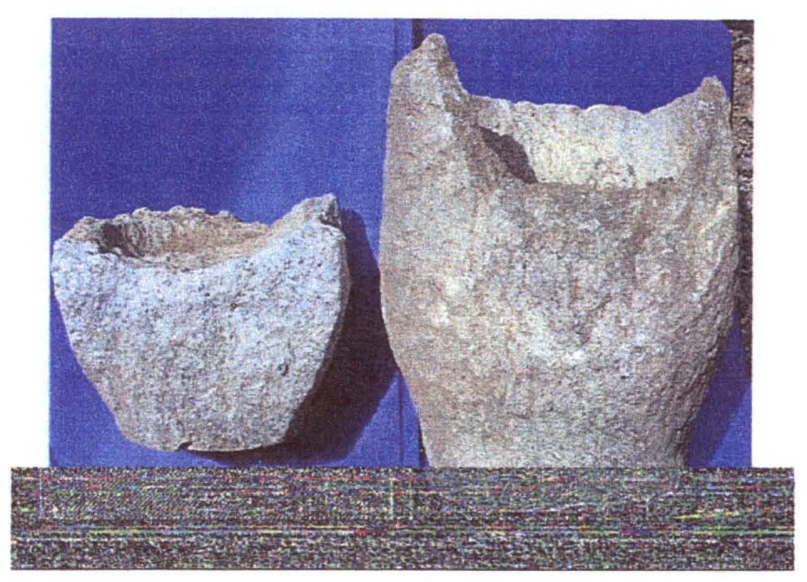

Figure 11. 
Preform \#2 is a broken soapstone bowl preform (Figure 12). It split vertically, but not into even halves. The piece that we found represents about $2 / 3$ of the preform's base. There are no obvious impurities where the bowl split. The preform once had side walls, but only a small amount of wall remains attached to the base. The preform has a classic flanged shape. The flange is about $1.5 \mathrm{~cm}$ high. The wall remnants are about $2 \mathrm{~cm}$ thick. Its height is $9.6 \mathrm{~cm}$. The outside diameter is 16.5 by $10 \mathrm{~cm}$ at the top of the wall remnants, and 10 by $7 \mathrm{~cm}$ at the base. All the manufacturing marks left on the bowl are consistent with manufacture by stone tools. Both the interior and exterior exhibit peck marks, but both surfaces are more weathered and smoother than preform $\# 1$.

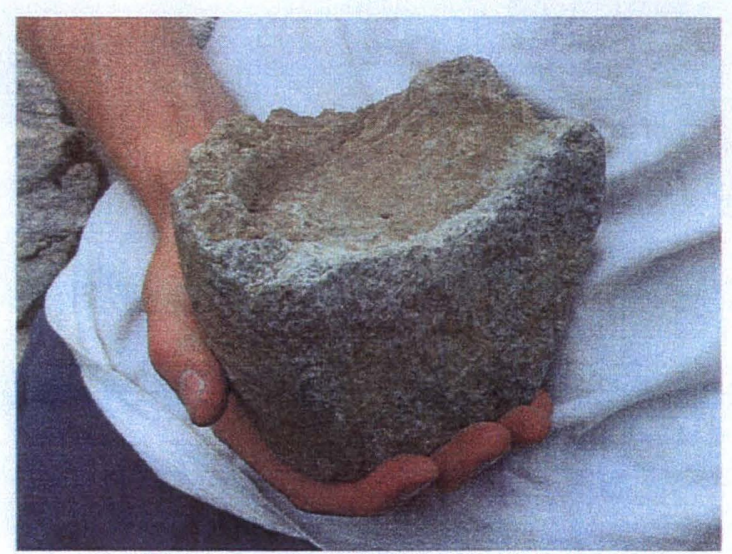

Preform \#2, 48TE1647

Figure 12.

Five pieces of a nearly completed, but subsequently broken, soapstone bowl were found in a 75 $\mathrm{cm}$ diameter area that was in close proximity to the preforms. Three of the fragments fit together and the other two fit together, but assemblies of the three and two do not fit together in any combination. No part of the base is present, but part of an irregular lip is present. There is no evidence of a flange. All the manufacturing marks left on the bowl are consistent with manufacture by stone tools. The manufacturing marks on the interior surface suggest a tool with an irregular edge that was used by a right handed person, because the manufacturing marks go from top right to bottom left. The exterior is more weathered and was chopped with a different tool that had an irregular edge. The height is estimated to be $15 \mathrm{~cm}$.

INTERPRETATION: I suspect that the site was a cache rather than a camp or manufacturing area. The ground slopes too much for comfortable camping and the site lacks soapstone "debitage" found at workshops in the Wind River Mountains (Adams 2003a).
This site and 48TE1644 (above) make a good argument for a prehistoric origin of the soapstone bowl industry. Sites with soapstone bowls and debitage are rare (Adams 1992, 2003b). About one-third of the vessels I have examined have metal tool marks. Usually there are historic artifacts superimposed over the prehistoric sign. In this case, the nearest historic artifacts are over $150 \mathrm{~m}$ south of the site. With the notable exception of 48NA580, where Frison (1982) recorded chipped stone tools and soapstone, few single component prehistoric soapstone sites have been recorded (Adams 1992).

TESTING: No testing was performed.

COLLECTION: No artifacts were collected. The soapstone artifacts were hidden under brush and rocks; the obsidian was not disturbed.

NATIONAL REGISTER STATUS: Although small and lacking in diversity, this is an important site. It contains soapstone artifacts with manufacturing marks consistent with stone tools in an unequivocally prehistoric context. Further study can be expected to yield significant scientific information. For this reason, 49TE1647 is considered eligible for nomination to the National Register of Historic Places.

IMPACTS: Other than the threat of collection by looters, no impacts are known.

RECOMMENDATIONS: Never in my 15-plus years as a professional archaeologist have I recommended collecting all the artifacts at a site, but in this case I think that it is important to collect the bowl fragments and both preforms as well as the obsidian debitage. Taken together, they are an important resource for further research.

SITE: 48TE1648 B Historic Mining area (Figures 13, and 14).

DESCRIPTION: This multi-component site consist of two mining test pits, one mine with a substantial adit and shaft, an old cabin, and prehistoric lithics. The site is in the Jedediah Smith Wilderness of the Caribou-Targhee National Forest on the west side of the Teton Range. Site size is $50 \mathrm{~m}$ NBS by $310 \mathrm{~m} \mathrm{E}-\mathrm{W}$ for an area of 12,175 $\mathrm{m} 5$. The mine is at an altitude of 9120 feet above sea level, the cabin and lithics are at 9080 feet, the cairn is at 9200 feet and the highest pit was at 9390 feet.

There is a mining test pit at the top of this site (Figure 13) in an iron-stained rock. Then there is another pit in gneiss (Figure 13). Neither pit exceeds $3 \mathrm{~m}$ in depth.

The mine represents a considerable amount of work. There is a horizontal adit, about $1.6 \mathrm{~m}$ in diameter, that goes back at least $10 \mathrm{~m}$ (Figure 14). A few meters 
into the mine a similarly sized vertical shaft drops down at least $3 \mathrm{~m}$ from the adit. There are greenish copper minerals in the mine tailings. It is not clear what was being mined, but there is no talc in any of the test pits or the mine.

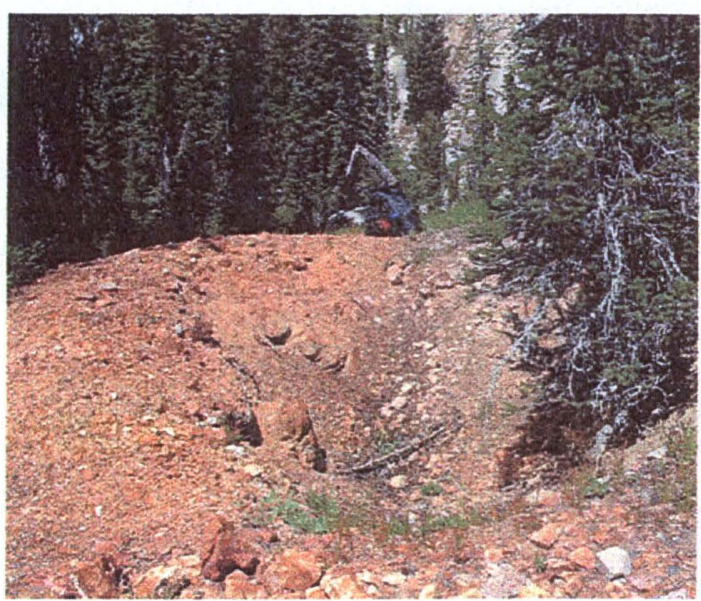

Test pit. Wypt 75 .

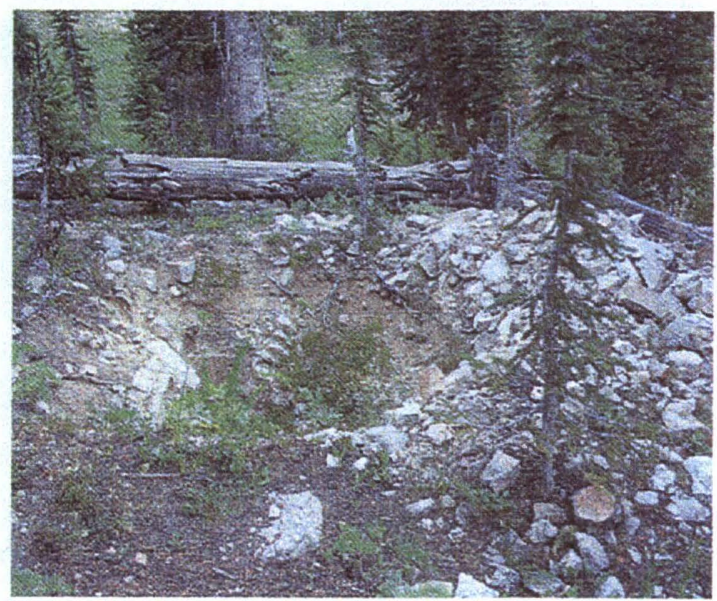

Test pit. Wypt 77.

Figure 13. Photographs of 48 TE1648

By all indications the cabin is old. The timbers were cut with an axe, not a saw. The logs are $\mathbf{V}$-notched and still fit tightly. Only five courses of logs remain and they are warped and sunken. Other than a solder-dot can fragment, no identifiable historic artifacts were recorded. Scattered about the flat spot near the cabin is a background noise of rust fragments that may have been from cans, but they are rusted beyond all archaeological utility.
The cairn looks to be of Euro-American origin The center is not filled in with rocks and it looks like a 4 by 4 inch post, used to mark mining claims, would fit in this space.

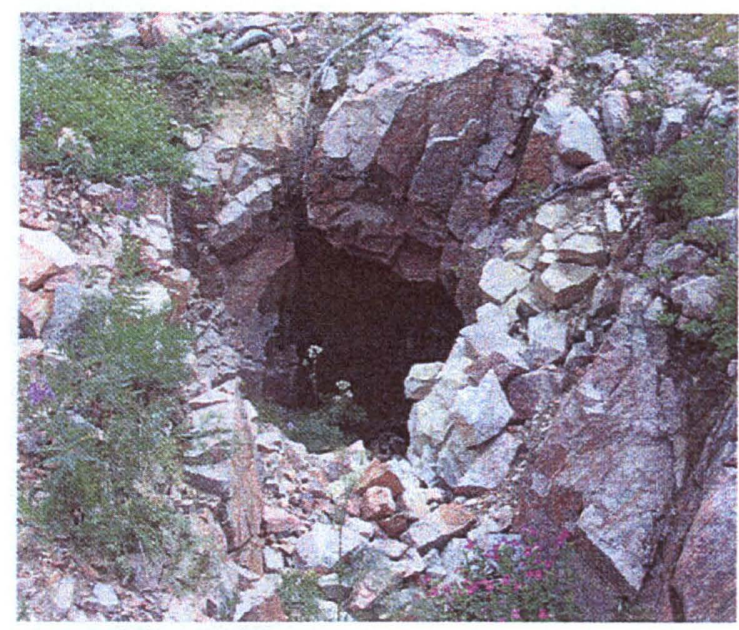

Mine opening.

Figure 14. Photograph of 48 TE1648

In addition to the historic mining features, seven prehistoric artifacts were found within the mine site boundary. Four of the seven prehistoric artifacts were within $30 \mathrm{~m}$ of the cabin. FS-1 is a cobble quartzite utilized flake tool (Figure 15). It measures 75 by 50 by $25 \mathrm{~mm}$ thick and there is about $65 \mathrm{~mm}$ of use along one edge. It was found within $30 \mathrm{~m}$ of three other pieces of debitage (grey obsidian debris, orthoquartzite secondary flake, and an ignimbrite secondary flake). It is unclear if the prehistoric artifacts were collected by the miners or if they predated the miners. Another three pieces of ignimbrite (two tertiary flakes and a biface thinning flake) were found about $40 \mathrm{~m}$ uphill of the cairn.

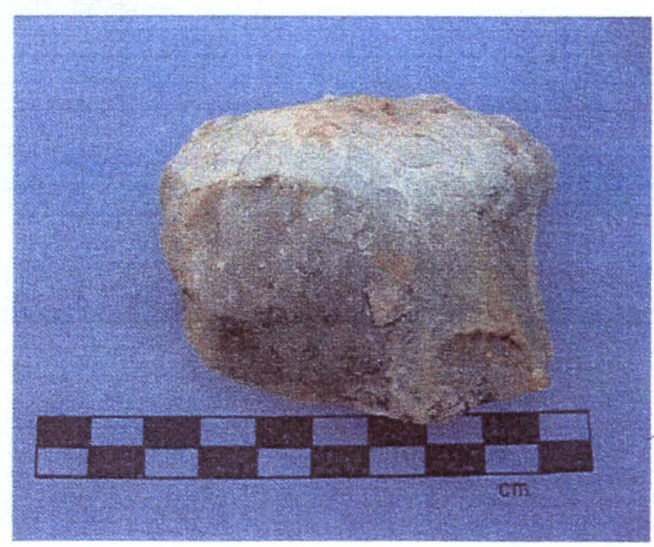

FS-1

Figure15 Photograph of 48TE1648 
TESTING: No testing was performed.

NATIONAL REGISTER STATUS: Unevaluated. Since we were doing aboriginal archaeology under the grant, very little time was spent recording the historic site.

IMPACTS: Other than the threat of collection by looters, no impacts are known.

RECOMMENDATIONS: A combination of historic research and more archaeology is recommended.

\section{Isolated Finds}

Four isolated prehistoric finds were located and recorded. They are described below.

IF-1 is the base of a Middle Archaic projectile point (Figure 16). It was found in the Caribou-Targhee National Forest on the west side of the Teton Range. It was found in the middle of the trail near Indian Meadows. The Indian Meadows trail passes through heavy whitebark pine timber. The point base was found about $50 \mathrm{~m}$ south of a unmodified soapstone boulder also found in the trail. The point base is made from high quality milky white chalcedony. It measures 17 by 20 by $5 \mathrm{~mm}$ thick. The base has not been ground. The base is most likely a Middle Archaic Hanna or Duncan projectile point (Frison 1991:91). The point base was collected and turned over to the Caribou-Targhee National Forest archaeologist.

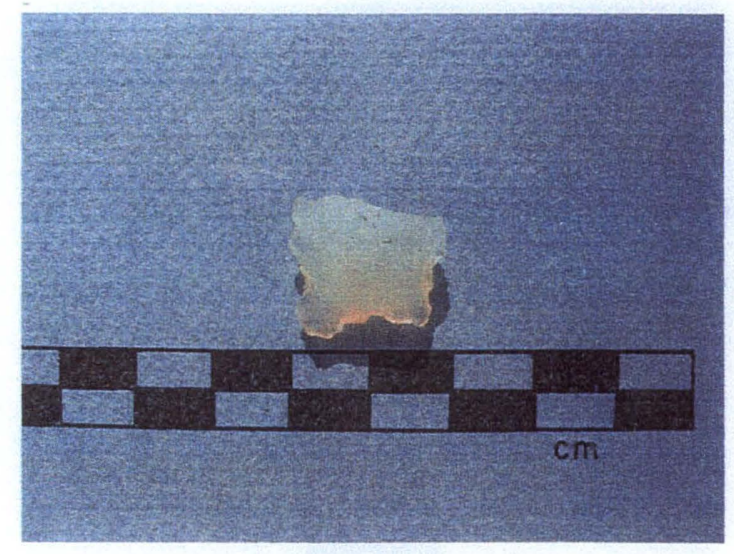

Figure 16. Photograph of IF-1.

IF-2 is a cairn on the edge of a gneiss outcrop overlooking the Badger Creek drainage. It is located about $100 \mathrm{~m}$ east of the Rammel Mountain soapstone quarry in the Jedediah Smith Wilderness of the CaribouTarghee National Forest on the west side of the Teton Range. The cairn is about $1 \mathrm{~m}$ high by $1.3 \mathrm{~m}$ in diameter and consists of at least two dozen rocks and is six courses high (Figure 17).

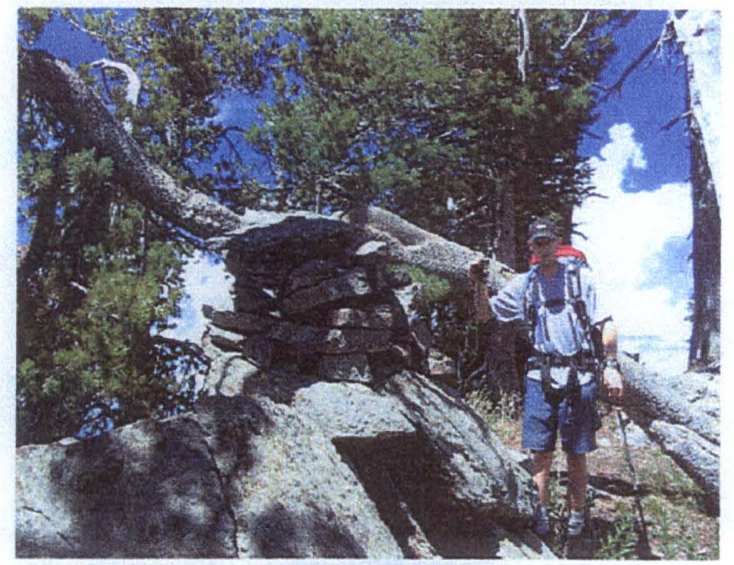

IF-2

Figure 17. Photograph of IF-2.

IF-3 (Figure 18) consists of two chunks of ignimbrite debris found on an unnamed pass on the flank of Rammel Mountain between the Indian Meadows and Bitch Creek drainages. The pass is grassy and surrounded by Krumholz. Both pieces are angular chunks of glassy ignimbrite a few centimeters on a side. They were not collected.

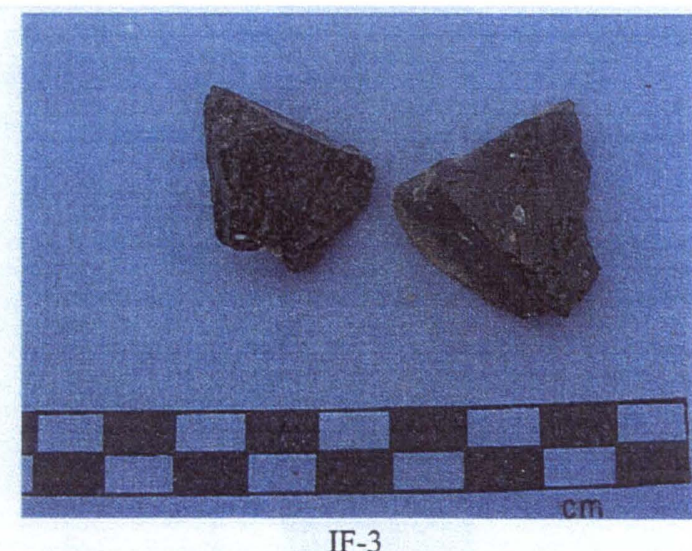

Figure 18. Photograph IF-3

IF-4 is a quartzite secondary flake found in the valley below 48 TE529 (Figure 19). It measures 7 by 5 by $2 \mathrm{~cm}$. It was detached from a rounded quartzite stream cobble. The flake was found in a meadow on the south side of Owl Creek in a pocket gopher mound. It was not collected.

\section{DISCUSSION}

Other archaeologists have made a case for northwestern Wyoming being the epicenter of the Rocky Mountain soapstone bowl industry (Marceau 1982; 
Wedel 1954), yet until this report, little fieldwork had been done to confirm this. Soapstone quarries and workshops in other Wyoming mountain ranges such as the Big Horns, the Winds, the Laramie Range are much better known and recorded (Adams 2003a; Frison 1982; Harris 1995b; Schoen and Vlcek 1991).

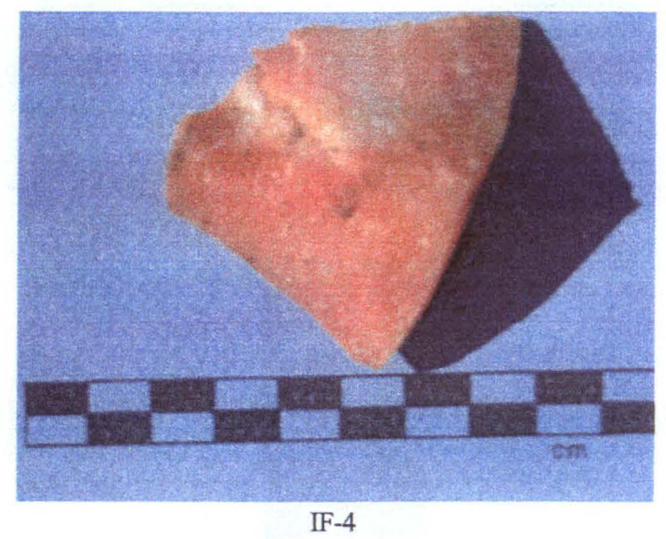

Figure 19. Photograph of IF-4.

During the first year of fieldwork, OWSA archaeologists visited three of the six ultramafic rock outcrop locations mapped by Love (et al. 1992). Traces of aboriginal use were found at one source on the west side of the Tetons (48TE1646). Historic mining at 48TE1255 may have obliterated any possible traces of aboriginal use. 48TE529 is an important aboriginal quarry according to C.M. Love (1971); however, we were unable to relocate the primary source.

The time depth of soapstone artifacts in Wyoming is great: A disc bead, found at the Hell Gap Paleoindian site, came from a level older than 9000 years ( Adams n.d.). Steatite beads were found at the Split Rock site in a feature dating to 5500 years ago (Eakin 1987). Soapstone pipes date to at least 4000 years ago (Frison and Walker 1984:38-39).

However, the antiquity of soapstone vessels is hard to prove. One bowl was AMS dated to AD 1848 (Adams 1992) and other bowl fragments were found at Protohistoric sites. At least one-third of the vessels I have examined have metal tool marks (Adams 1992). The discovery of soapstone bowls and chipped stone at 48TE1647 B where two bowl preforms and a broken bowl exhibit manufacturing marks consistent with stone, not metal, tools B is considered to be unambiguous evidence of prehistoric bowl manufacture. Soapstone debris was also found associated with prehistoric artifacts at $48 \mathrm{TE} 1644$.

\section{MANAGEMENT RECOMMENDATIONS}

In the first year of an expected three year project, archaeologists and volunteers surveyed more than 130 acres and recorded eight sites in Grand Teton National Park and Caribou-Targhee National Forest. We visited and recorded sites in GTNP that lacked formal documentation and found six new sites in the CaribouTarghee National Forest.

More work is recommended at 48TE529 in Grand Teton National Park. While a secondary source of soapstone was located, the aboriginal quarry described by Charlie Love was not re-located. This is one of the closest sources to the Lawrence site, which had the highest concentration of soapstone artifacts of any known archaeological site in Wyoming.

Site 48TE1647 has evidence of prehistoric manufacture of soapstone bowls. Complete collection of this site is recommended. Based on findings on the west side of the Tetons in the Caribou-Targhee National Forest, I believe that there is good potential for the discovery of aboriginally-utilized soapstone sources in the Bitch Creek area. More work is recommended in this area.

If another year of funding is obtained by the author, the team is committed to locating and recording additional soapstone sources in both Grand Teton National Park and in the Caribou-Targhee NF.

\section{$\downarrow$ ACKNOWLEDGMENTS}

Without funding from state and federal agencies this project would not have been possible. My special thanks go to the University of Wyoming-National Park Service Research Station grant committee that decided to fund this project. Steve Buskirk was immeasurably helpful, taking us across Jackson Lake and providing accommodation at the always full AMK Ranch. His support of archaeology is greatly appreciated.

Thanks for NPS/GTNP archaeologist Jaquelin St Clair and her seasonal assistant Lucy Harris for coming along.

Special thanks to Sharon Long at the Cultural Records Office for help with the legal locations of the sites. 
The crew consisted of Yvette Widman, RobinK. Hill, Stephan P. Edwards, and Mary Springer. Special thanks to go to Steve, who shot the video that captured the discovery of the soapstone bowls.

A generous Allbright grant made travel to the Tetons possible.Office of Wyoming State Archaeologist Dave Eckles has always supported independent research. Yvette Widman created the graphic images that brighten potentially dull site reports. All errors and omissions are solely the responsibility of the author.

\section{LITERATURE CITED}

Adams, Richard. 2003a. An Archaeological Reconnaissance of the Soapstone Lake District, Fitzpatrick Wilderness, Fremont County, Wyoming. Report prepared for the Shoshone National Forest. Copies on file at the Cultural Records Office, Laramie.

2003b A Context for the Upper Greybull River Soapstone Pipe Fragment. Report prepared for Dr. Lawrence C. Todd, Colorado State University.

2002a Powder X-Ray Diffraction, Scanning Electron Microscope Imagery and Spectrography of Soapstone Samples from Eight Locales in Wyoming and France. Paper prepared for GEOL 5630 - Electron Microprobe.

2002b Analysis of an Atlatl Weight Fragment from 48NA182. Report prepared for Dust Devil Archaeology. Copies on file at the Cultural Records Office, Laramie.

1992 Pipes and Bowls: Carved Steatite Artifacts from Wyoming and the Region. Unpublished Masters Thesis, Department of Anthropology, University of Wyoming, Laramie.

Adams, Richard and Mary Jane Daniels. 1995. A Radiocarbon Date on the Residue Adhering to a Steatite Vessel from Southern Wyoming. The Wyoming Archaeologist 39(1-2):11-19.
Chapman, R.C.1977. Analysis of the lithic assemblages. In Settlement and subsistence along the lower Chaco: The CGP Survey, edited by Charles A. Reher, pp. 371 - 452. University of New Mexico Press, Albuquerque.

Connor, M. 1990. 48TE1255 site form. On file at the Cultural Records Office, Laramie.

Eakin, Daniel H. 1987. Final report of salvage operations at the Split Rock Ranch site (48FR1484). Highway Project SCPF-0202(19), Fremont County, Wyoming. Prepared by the Office of the Wyoming State Archaeologist for the Wyoming Highway Department. Onfile at the Cultural Records Office, Laramie.

Frison, George C. 1991. Prehistoric Hunters of the High Plains, Second Edition. Academic Press, San Diego.

1982 Sources of steatite and methods of procurement and use in Wyoming. Plains Anthropologist 27: 273-286.

Frison, George C, and Danny Walker (editors). 1984. The Dead Indian Creek site: and Archaic occupation in the Absaroka mountains of Northwestern Wyoming. The Wyoming Archaeologist 27(1-2):11-119.

Harris, Ray E. 1995a. Asbestos and Serpentine in Wyoming. Industrial Minerals Report 95-2. Wyoming State Geological Survey, Laramie.

1995b Talc, including steatite in Wyoming. Open File Report 95-1. Wyoming State Geological Survey, Laramie.

Ladoo, Raymond B. and W.M. Myers. 1951. Nonmetallic Minerals, second edition. McGraw-Hill, New York.

Larson, T.A. 1965. History of Wyoming. University of Nebraska Press.

Love, Charles M. 1971. 48TE529 Site Form. On file at the Cultural record Office, Laramie. 
1972 An Archaeological Survey of the Jackson Hole Region, Wyoming. Unpublished Masters Thesis, Department of Anthropology, University of Wyoming, Laramie.

Love, J.D. 2002. Personal communication with Richard Adams, 5/23/02.

Love, J.D., John C. Reed, Jr., and Ann Coe Christiansen. 1992. Geologic Map of Grand Teton National Park, Teton County, Wyoming. United States Geological Survey, Miscellaneous Investigations Series, MAP I-2031.

Love, J.D. and Ann Coe Christiansen. 1985. Geologic Map of Wyoming. Geologic Survey of Wyoming, Laramie.

McKee, Dave. 1988. A faunal analysis of the River Bend site (48NA302): evidence of Protohistoric subsistence on the Northwest Plains. Unpublished Masters Thesis, Department of Anthropology, University of Wyoming.

Malainey, Mary. 2003. Email to Richard Adams $(2 / 28 / 03)$ with preliminary results of gas chromatography of lipids adhering to prehistoric and replicated soapstone bowls.

Marceau, Thomas E. 1982. Steatite, Intermountain pottery, and the Shoshone: some preliminary considerations. The Wyoming Archaeologist 25(1-2):11-32.

no date Steatite, Intermountain pottery, and the Shoshone: problems in association. Unpublished manuscript.

Norris, P. W. 1881. 5th Annual Report of the Superintendent, Yellowstone National Park. U.S. Government Printing Office, Washington, D.C.
Sanders, Paul H. 1995. The Bruce $=$ s Bridge Site 948FR3305): 8000 Years of Prehistory in Sinks Canyon, Wyoming. report prepared for the Federal Highway Administration by the Office of the Wyoming State Archaeologist. Copies on file at the Cultural Records Office, Laramie.

Schoen, James R. and David T. Vlcek. 1991. Steatite procurement and source areas in Western Wyoming. Paper presented at the Northwestern Plains Archaeological Symposium, Billings, Montana, April 1991.

Shepherd, Ruth A. 1992. A Cultural Model for Groundstone Use in the Middle Rocky Mountains: The Helen Lookingbill Site. Unpublished Masters Thesis, Department of Anthropology, University of Wyoming, Laramie.

Thwaites, R. C., editor. 1904. Original Journals of the Lewis and Clark Expedition. Antiquarian Press, New York.

Turner, Jack. 2000. Teewinot: Climbing and Contemplating the Teton Range. St. Matrin's Press, New York.

Wedel, Waldo R. 1954. Earthenware and steatite vessels from northwestern Wyoming. American Antiquity 19:403-409.

Wells, J. Robert. 1974. Talc, soapstone, and pryophyllite in 1974. Annual Advance Report U.S. Department of the Interior, Bureau of Mines. U.S. Government Printing Office.

Wright, Gary A. 1984. People of the High Country: Jackson Hole Before the Settlers. Peter Lang, New York. 


\section{APPENDIX}

\section{OBSERVATIONS ON SOAPSTONE GEOLOGY IN THE TETON RANGE}

By

\author{
Yvette A. Widman
}

The Tetons are the youngest mountains in the Rocky Mountain system. The Teton Range is a result of two major tectonic episodes. The first was during the Laramide Orogeny (80-65 million years ago). The second began nine million years ago, with most of the uplift taking place within the last five million years and the range has been rising since (Love et al 2003:1).

The Teton system is comprised of two structures: the Teton Range is "an up-faulted block tilted to the west. And Jackson Hole, [which is] a narrow, down dropped fault block" (Harris 1995:558). Looking north, the western flank of the range is comprised of downward dipping Paleozoic rocks. The peaks are of Precambrian granite with intrusive dikes. Some, like Mt. Moran, are capped with Cambrian Period sedimentary deposits (Flathead Sandstone). These are bounded to the east by the steeply dipping Teton normal fault (Gilmer 1986:42).

Based on strontium-rubidium dates, the Precambrian rocks are approximately 2.5 billion years old (Harris et al 1995:558). They include layered granitic gneisses (a metamorphic rock that has foliations), granites, migmatites, diabase dikes, and small ultramafic pods of dark green serpentine. These pods are associated with the steatite deposits.

Steatite or soapstone is a variant of talc. Talc $\left(\mathrm{Mg}_{3} \mathrm{Si}_{4} \mathrm{O}_{10}(\mathrm{OH})_{2}\right)$ is a phyllosilicate and when it is found in a compact and massive form it is referred to as steatite or soapstone (Hurlbut and Klein 1977). Soapstone has a dark grey or green color, is translucent, and characterized by its greasy feel and luster. The crystallography of talc is described as "...monoclinic; $2 / m$ (one rotation axis with perpendicular mirror). Usually tabular with rhombic or hexagonal outline. Foliated and in radiating foliated groups" (Hurlbut and Klein 1977:403). It is a secondary mineral resulting from low-grade metamorphism of magnesium silicates such as olivine, pryoxenes, and amphiboles (Hurlbut and Klein 1977).

Three steatite outcrops in the Tetons were examined -- Slim's Asbestos Mine, Owl Peak, and the Rammel Mountain Quarry.

\section{TE1255 B Slim's Asbestos Mine}

The mine is located in the Berry Creek drainage in the northern part of the range. It is in a 50 meter wide outcropping of Late Archean metamorphic rocks comprised of layered gneiss and ultramafic rocks. The outcrop is just east of the Forellen Peak Fault. These rocks were metamorphosed approximately $2,815 \mathrm{Ma}$ (Love et al 1992). The gneiss is biotite rich B no feldspar crystals were observed. Veins of quartzite occur throughout the outcropping. The ultramafic rocks include lineations of long, brown asbestos fibers in the gneiss near the mine opening. Steatite cobbles can be found in the talus slope below the mine and there is a boulder near the mine opening which has a $15 \mathrm{~cm}$ rind of steatite.

\section{TE529 B Owl Peak}

The quarry was not located, however we found steatite cobbles on our approach from Owl Creek. The area surveyed was in Precambrian deposits --primarily gneiss. Madison Limestone outcrops to the west on Elk Mountain. Love's map (Love et al 1992) shows the quarry in the Precambrian layered gneiss and is about the same distance east of the Forellen Peak Fault as Slim's Mine in the next drainage north. The map does not show an outcropping of the ultramafic rocks as is associated with Slim's Mine and the Rammel Mountain Quarry.

\section{TE1646 B Rammel Mountain Talc Quarry}

The quarry is geologically mapped as a pod of Precambrian ultramafic rocks which is surrounded similar aged gneiss and is immediately north of a Proterozoic diabase dike which was emplaced before 1,450 Ma (Reed et al 1973, Love et al 1992). It is located on a small shelf below the Badger Creek Rim, near Rammel Mountain. The quarry consists of four pits excavated along a northerly trend.

Three lithologic units were described. These units are labeled from top to bottom as Strata I, II, and III. The units consist of two bands of gneiss (Strata I and III) which are partitioned by a steatite vein (Stratum II).

Stratum I is approximately 1.25 meters thick in pit 3. A shelf of this gneiss is slightly exposed above the pit itself. The gneiss is characterized by a slightly darker color than the gneiss in Stratum III. The mineralized laminae are thicker (up to two $\mathrm{cm}$ ), more convoluted than the lower gneiss, and are comprised of what looks like small crystals $(0.1-0.2 \mathrm{~mm})$ of quartzite, plagioclase, and an unidentified red crystal. The contact between this stratum and stratum II is not well defined. 
Stratum II is the steatite vein. It is a relatively homogenous bed up to two meters thick in quarry pit 1 , and tapers down to 1.25 meters thick in pit 3 . There are subtle, gradational changes in the steatite vein near the contacts with Strata I and III. The upper part of the vein, near Stratum I, is harder and has a slight color change, possibly due to staining from the upper bed. The lower contact is also characterized by a change in hardness. In addition, there is a crystalline change. The lower portion of the bed is a laminated schist that grades into a hard, fibrous, steatite. This rind which is $20 \mathrm{~cm}$ thick, with laminae no larger than $5 \mathrm{~cm}$ thick, has a darker green hue to it and could be serpentine. The contact between Strata II and III was beautifully exposed in quarry pit 2 .

Stratum III is a layered gneiss. There is a massive quartzite layer ( $15 \mathrm{~cm}$ thick) immediately below Stratum II. The main body is a biotite rich gneiss where the biotite is laminated and looks like crossbeds from a low velocity flow. There are veins of quartz and plagioclase crystals interspersed throughout the stratum. The average size of the crystals is slightly larger than quartz and plagioclase veins in Stratum I.

\section{$\downarrow$ DISCUSSION}

All three mines are located in Precambrian gneiss. Both Slim Lawrence's Asbestos Mine and the Rammel Mountain Indian soapstone quarry are directly associated with small pods of ultramafic rocks (Love et al 1992 and Reed et al 1973). One other known talc outcropping, near Bitch Creek Narrows is also geologically mapped as pod of ultramafic rock surrounded by Precambrian gneiss. It would not be surprising to find the Owl Peak Mine directly associated with a small outcropping of ultramafic rocks.

The ultamafic rocks seem to be regional, suggesting a localized tectonic event. All outcrops are located in the northern half of the Teton Range (Love et al 1992). In addition to the ultramafic outcrops found at Berry Creek and Rammel Mountain, there is a smattering of mapped ultamafic rocks in Waterfalls Canyon, southeast of Ranger Peak. Interestingly, some of these pods are east of the Forellen Peak Fault, as in the case of the both Slim's Mine and the Owl Peak Mine. The southern most outcrop of ultramafic rocks is in Moran Canyon, east of the confluence of the North Fork and the South Fork of Moran Creek. All of these locales should be examined for possible sources for steatite.

\section{$\downarrow$ LITERATURE CITED}

Gilmer, Douglas R. 1986. The Teton Mountains and Jackson Hole region. In A Geologic Tour of Wyoming From Laramie to Lander, Jackson and Rock Springs. The Geological Survey of Wyoming Public Information Circular No. 27. Laramie, Wyoming.

Harris, Ann G., Esther Tuttle, and Sherwood D. Tuttle. 1995. Geology of National Parks Fifth Edition. Kendall/Hunt Publishing Company, Dubuque.

Hurlbut, Cornelius S. Jr., and Cornelis Klein. 1977. Manual of Mineralogy (after James D. Dana) $19^{\text {th }}$ edition. John Wiley and Sons, New York.

Love, J. David, John C. Reed, Jr., and Ann Coe Christiansen. 1992. Geologic Map of Grand Teton National Park. Teton County, Wyoming. U.S. Geological Survey Miscellaneous Investigations Series Map I-2031.

Love, J. David, John C. Reed, Jr., and Kenneth L. Pierce. 2003. Creation of the Teton Landscape: A Geologic Chronicle of Jackson Hole and the Teton Range. Grand Teton Natural History Association in cooperation with the National Park Service. Moose.

Reed, John C. Jr., David W. Love, and J.D. Love. 1973. Preliminary Geologic Map of the Rammel Mountain Quadrangle, Teton County, Wyoming. U.S. Geological Survey Open-file report. 